\title{
Substrate selection and use of protective cover by juvenile Atlantic cod Gadus morhua in inshore waters of Newfoundland
}

\author{
Robert S. Gregory ${ }^{1, *}$, John T. Anderson ${ }^{2}$ \\ 'Ocean Sciences Centre, Memorial University of Newfoundland, St. John's, Newfoundland, Canada A1C 5S7 \\ ${ }^{2}$ Ocean Ecology Division, Science Branch, Department of Fisheries and Oceans, St. John's, Newfoundland, Canada A1C $5 X 1$
}

\begin{abstract}
We investigated the habitat preferences and use of cover of 1 to 4 yr old juvenile cod Gadus morhua in the inshore waters (18 to $150 \mathrm{~m}$ depth) of Placentia Bay, Newfoundland, Canada, using deep sea submersibles (PISCES IV \& SDL-1) in April 1995. We analysed a total of $32 \mathrm{~h}$ of 'onbottom' videotape, audiotape, and written records from 9 daylight dives and 1 night dive. Habitat types were characterised by depth, substrate particle size, bathymetric relief, and the presence or absence of macroalgae. Juvenile cod found throughout the dive area were identified as either 'young' (age 1, 10 to $12 \mathrm{~cm}$ total length, and mottled in colour) or 'old' (age 2 to $4,>15 \mathrm{~cm}$ total length, and relatively uniform in colour). Of old juveniles, $80 \%$ were found to be associated with areas of coarse substrate and high bathymetric relief (i.e. submarine cliffs). In contrast, $59 \%$ of young juveniles were found primarily in areas with a gravel substrate and low relief. Juvenile cod did not exhibit selection for substrates with macroalgae cover. We did not identify any difference between day and night observations. Old juveniles were often associated with individual substrate features (e.g. a single rock, boulder, or crevice), and exhibited a significant increase in activity (oriented swimming speed) with increasing distance from such features. Young juveniles exhibited no such association with specific substrate features, although they exhibited greater variation in activity (non-oriented swimming speed). The observed patterns in activity between the age groups suggest a difference in predator avoidance behaviour. Young mottled individuals appeared to be relying on crypsis, whereas older uniform-coloured juvenile cod associated with a specific physical feature which represented cover. Our results corroborate the findings of previous laboratory and shallow water field studies on the behaviour of this species. In addition, these results demonstrated that substrate selection by juvenile cod is age specific.
\end{abstract}

KEY WORDS: Habitat selection · Bottom cover - Submersibles - Placentia Bay · Coastal bays · Predator avoidance PISCES IV $\cdot$ SDL-1

\section{INTRODUCTION}

In the pelagic stage, juvenile Atlantic cod occur throughout the offshore and inshore waters of Newfoundland, Canada (Anderson et al. 1995). These juveniles settle and become demersal in coastal bays (Methven \& Bajdik 1994, Dalley \& Anderson in press, Ings et al. in press) and offshore banks, such as the Grand Bank (Walsh et al. 1995), which act as nursery areas. These and other studies (Lear et al. 1980, Riley \& Parnell 1984) have shown that juvenile cod move from

\footnotetext{
•E-mail: bgregory@athena.nwafc.nf.ca
}

shallower to deeper waters as they mature from age $0+$ through age 4 , but do not intermingle with adult cod until approximately age 3 to 4 (Templeman 1979). It has been suggested that the use of shallower waters by younger age classes reduces predation by older conspecifics (Riley \& Parnell 1984). However, other than the demonstrated preference of substrate types which may provide safety for age $0+$ from older conspecifics (Gotceitas \& Brown 1993), little is known of the interactions or partitioning of habitat between various age classes of cod cohabiting in the wild. In waters greater than $20 \mathrm{~m}$ depth, where age 1 and older individuals spend most of their time (Keats et al, 1987, Clark \& 
Green 1990, Keats 1990, Wigley \& Serchuk 1992), juvenile cod distributions and their associations with substrate are poorly known. From observations made in the nearshore ( $<20 \mathrm{~m}$ depth), it has been suggested that juvenile cod occupy progressively deeper waters and associate with coarser substrates as they grow (Keats et al. 1987, Clark \& Green 1990). Due to the inherent difficulties of conducting winter observations, knowledge of the behaviour of juvenile cod in the wild at this time of year is virtually non-existent.

Much of the lack of information on behaviour of individual juvenile cod is due to technical constraints. Insights on behaviour and habitat selection of juvenile Atlantic cod and other demersal species have generally been based on observations of aggregations sampled by offshore and inshore research surveys using modified or commercial fishing gear (e.g. Wigley \& Serchuk 1992, Anderson et al. 1995, Walsh et al. 1995), by SCUBA in nearshore waters $(<20 \mathrm{~m})$ (Keats et al. 1987, Keats 1990, Clark \& Green 1991, Tupper \& Boutilier 1995a, b), or in laboratory mesocosm experiments (Gotceitas \& Brown 1993, Gotceitas et al. 1995, Fraser et al. 1996). While these studies have provided valuable information on distribution in relation to habitat, all have their limitations. Identification of aggregations of fish from research surveys tell us a great deal about where fish are, but they tell us little about why they are in a particular place at a particular time. Also, limitations of trawls (Krieger 1993) and hydroacoustics (Starr et al. 1996) in sampling rocky habitat impose serious constraints on our interpretation of habitat use, especially for demersal forms. Nearshore SCUBA studies have the advantage of being able to tell us more about the association of individual fish with habitat, but they have the disadvantage of not being able to cover the potential range of habitats occupied by dem-
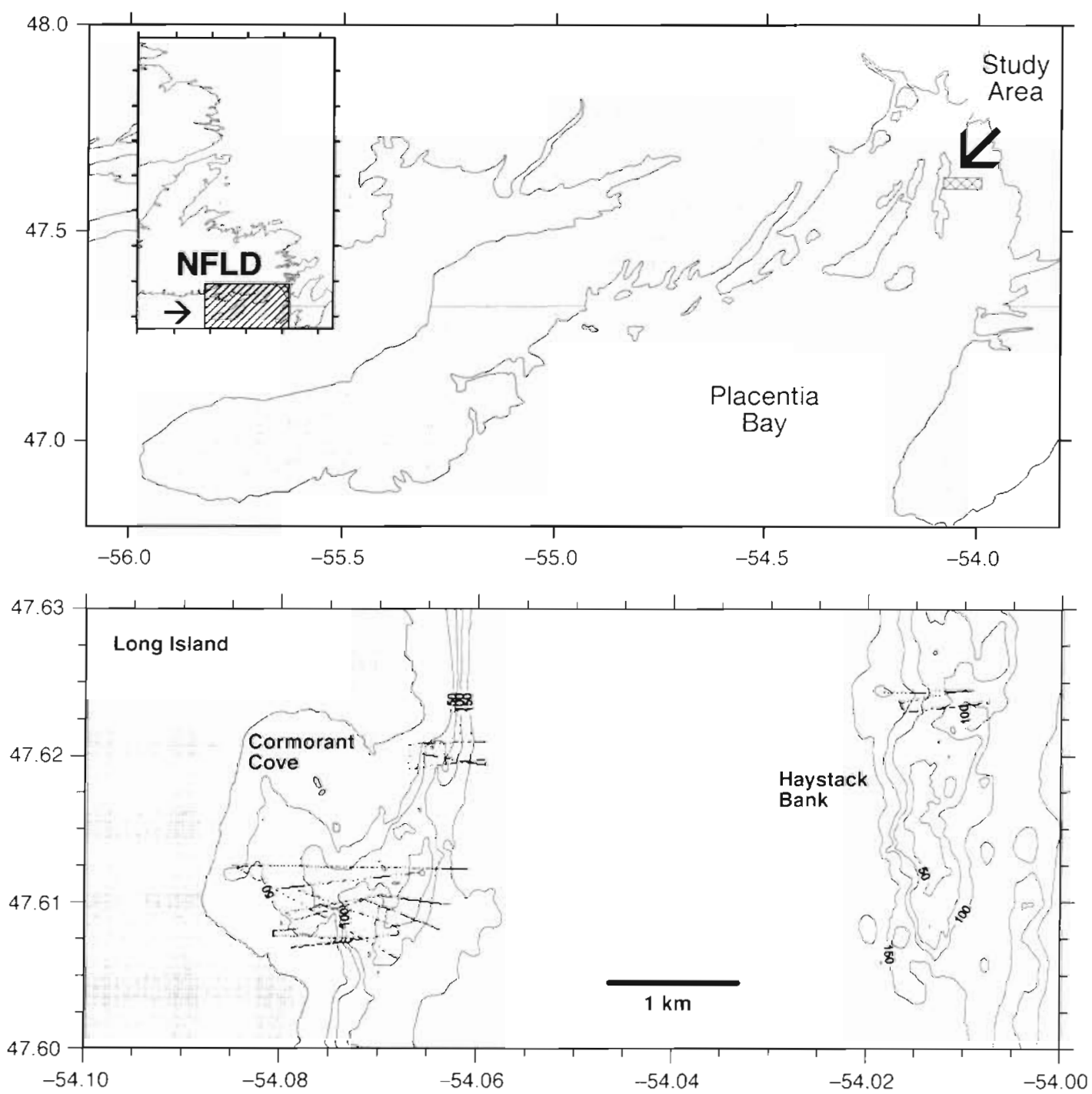

Fig. 1. (A) Study area, and (B) submersible dive tracks, in Placentia Bay, Newfoundland, 21 to 25 April 95 (bathymetry in meters) 
ersal species throughout much of their early lives. Laboratory studies have been successful at investigating specific mechanisms explaining habitat selection (such as predator avoidance behaviour or feeding behaviour), but can suffer from limited applicability to the field. Observations of the behaviour of individual fish at depths beyond SCUBA capability are made possible only by remotely operated vehicles (ROVs) equipped with appropriate cameras, or by manned submersibles (e.g. Able et al. 1982, Grimes et al. 1986, Lough et al. 1989, Edsall et al. 1993, O'Connell \& Carlile 1994).

In this study, we conducted observations of behaviour and habitat use of individual juvenile Atlantic cod from manned submersibles. We describe in situ observations of juvenile Atlantic cod behaviour and substrate association which both support reported findings from previous laboratory and inshore studies, and suggest behavioural explanations for age-specific differences in these associations.

\section{STUDY AREA}

Our study area was located near Long Island and Haystack Bank at the head of Placentia Bay, Newfoundland, Canada $\left(47^{\circ} 37^{\prime} \mathrm{N}, 54^{\circ} 04^{\prime} \mathrm{W}\right.$; Fig. 1). Placentia Bay is a fjord which, near our study site, extends to a depth of $360 \mathrm{~m}$. Haystack Bank rises to a depth of $18 \mathrm{~m}$ at its shallowest point and runs $6.1 \mathrm{~km}$ north to south, and $1.6 \mathrm{~km}$ east to west, at the $200 \mathrm{~m}$ contour. Cormorant Cove is located off the eastern shore of Long Island in the above area, and is approximately $2.0 \mathrm{~km}$ north to south, and $1.5 \mathrm{~km}$ east-west. The cove has a maximum depth of $112 \mathrm{~m}$.

The study area was heterogeneous with respect to bathymetric relief, substrate particle size, and presence of macroalgae (Fig. 2). Relief ranged from flat areas extending for several hundred meters to cliffs rising $50 \mathrm{~m}$ from the sea floor. Within the immediate vicinity of the dive areas (2 areas in Cormorant Cove
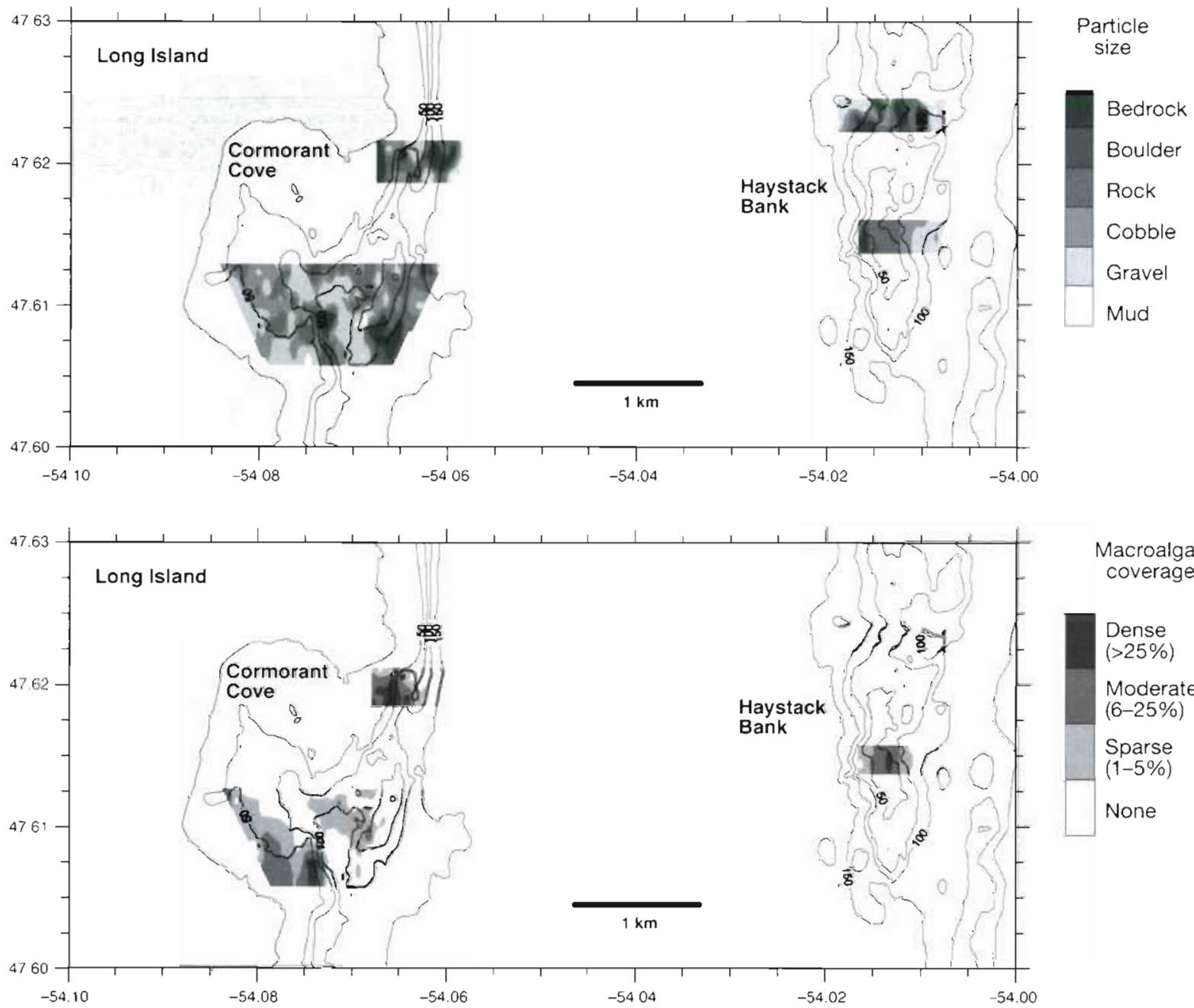

Macroaigae coverage

Dense $(>25 \%)$ Moderate $(6-25 \%)$

Sparse $(1-5 \%)$

None

Fig 2. (A) Substrate particle size, and (B) percentage of macroalgae coverage, within the immediate vicinity of the 4 dive areas, and bathymetry of the study area, April 1995 
and 2 areas on Haystack Bank), the bottom substrate varied in composition from mud/silt $(<0.1 \mathrm{~cm}$ diameter) to bedrock. The distribution of major substrate types (defined in 'Methods') was patchy and often related to bathymetric relief. Areas of high relief ran in several series of cliffs and ridges oriented roughly parallel to shore. We found much of the cobble, rock and boulder at the base and tops of these ridges and cliffs, which themselves consisted of bedrock. In much of the low relief areas, the substrate was dominated by gravel/ sand deposits $(0.1$ to $2.0 \mathrm{~cm}$ diameter $)$ with a fine layer of mud/silt. Substrate deeper than $200 \mathrm{~m}$ in this area was generally dominated by mud/silt (Gregory et al. 1996). Macroalgae, including Irish moss Chondrus crispus and kelps Laminaria digitata and Agarum cribrosum, was generally found at depths $<40 \mathrm{~m}$ and in several locations approached $100 \%$ coverage of the bottom. Small ( 1 to $5 \mathrm{~m}^{2}$ ), dense patches of Irish moss were observed as deep as $80 \mathrm{~m}$, which appeared to be the maximum depth of the photic zone.

On 24 April 1995, the study area in Cormorant Cove exhibited water temperatures of $5.5^{\circ} \mathrm{C}$ at the surface, declining to $-1.0^{\circ} \mathrm{C}$ at $75 \mathrm{~m}$. There was no thermocline evident (Fig. 3). The ambient water temperature at which observations of juvenile cod were made in this study ranged between -1.0 and $0.5^{\circ} \mathrm{C}$. There was a slight tidal current ( $\max 0.1$ to $0.2 \mathrm{~m} \mathrm{~s}^{-1}$ ) in the study area, but its effect was negligible (e.g. undisturbed fine silt was encountered throughout the study area).

\section{METHODS}

PISCES IV and SDL-1 are deep-sea, free-diving submersibles capable of operating at depths of $2000 \mathrm{~m}$ and $610 \mathrm{~m}$ respectively. During the course of our study, dive operations were generally limited to depths shallower than $150 \mathrm{~m}$. Both submersibles were battery-powered, could be operated for mission lengths of up to $6 \mathrm{~h}$ duration, and had a cruise speed of $30 \mathrm{~m} \mathrm{~min}^{-1}$ (60 and $45 \mathrm{~m} \mathrm{~min}^{-1}$ maximum, respectively). During our study, PISCES IV carried a crew of 3 ( 1 or 2 pilots and up to 2 scientific observers) and was equipped with an external video camera (with VHS recorder) as well as an internal $35 \mathrm{~mm}$ camera linked to an external strobe light. Visual observations were made through any of 3 view ports. SDL-1 carried a crew of 4 (2 pilots and 2 scientific observers), and was equipped with 2 external video cameras and a large forward-facing view port. External lighting was provided either by two $1000 \mathrm{~W}$ and two $500 \mathrm{~W}$ quartz lights (PISCES IV) or three $1000 \mathrm{~W}$ and two $250 \mathrm{~W}$ quartz lights (SDL-1). All observations reported in this paper were made under artificial light, regardless of the prevailing ambient light conditions, in order to maintain consistency. The 2 submersibles were

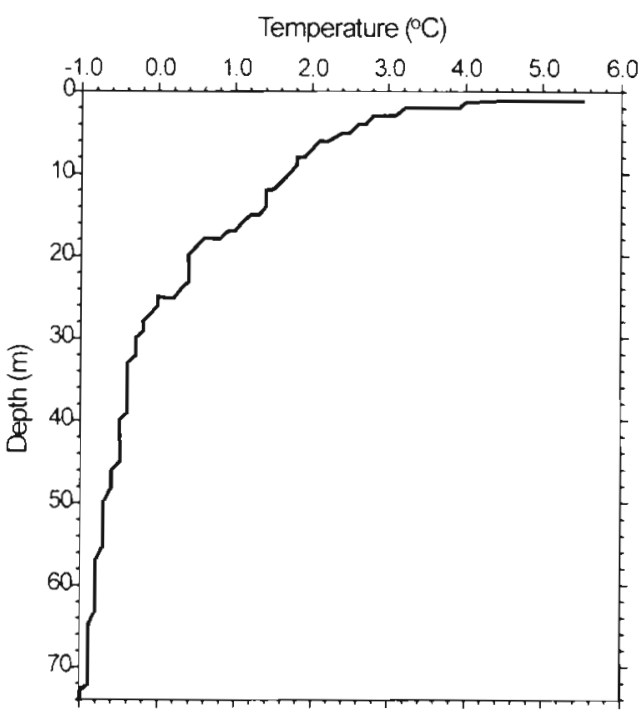

Fig. 3. Vertical temperature profile of Cormorant Cove، 24 April 1995

maintained aboard the Canadian Navy submarine tender vessel, HMCS 'Cormorant'.

Location of submersibles on the bottom was determined by cross-referencing transponder signals, using an Honeywell 906 tracking system, with the position of the HMCS 'Cormorant' which was obtained by GPS. By analysis of bottom position in instances where the submersibles were known to be stationary, we have been able to verify the accuracy of the tracking system to within $16 \mathrm{~m}$.

We conducted 9 daylight dives and 1 night dive with the 2 submersibles in the study area, during April 4-5 and April 22-25, 1995 (Table 1). Day dives began between 08:00 and 09:30 h, and concluded by 15:30 h The night dive was conducted from 20:55 to $23: 15 \mathrm{~h}$. Of the 10 dives, 4 were conducted using PISCES IV. The remainder, including the night dive, were conducted using SDL-1. In total, we collected 32 h of 'on bottom' videotape, audiotape, and written observational records in $18.2 \mathrm{~km}$ of transects. The speed of the submersibles on bottom varied between zero and $30 \mathrm{~m} \mathrm{~min}^{-1}$. We made 8 dives in Cormorant Cove ( 7 day, 1 night) and 2 dives on Haystack Bank (Table 1, Fig. 1).

We collected videotape records continuously while the submersibles were on the bottom. These records were used as the primary means of identifying substrate type. Audio records (both by separate recorder and with the videotape) and written records were taken to complement the video record. Substrate characteristics were recorded at 5 min intervals, or more frequently if these characteristics changed significantly. Audio and written notes of any cod observed and estimates of age or length (or both) were also 
Table 1 Location, time of day, linear distance surveyed, and on-bottom duration of submersible dives in Placentia Bay. Newfoundland, in April 1995

\begin{tabular}{|c|c|c|c|c|c|c|}
\hline $\begin{array}{l}\text { Date } \\
\text { (1995) }\end{array}$ & Submersible & $\begin{array}{l}\text { Dive } \\
\text { no. }\end{array}$ & Location & Position ${ }^{a}$ & $\begin{array}{c}\text { Dive } \\
\text { duration (h) }\end{array}$ & $\begin{array}{c}\text { Dive } \\
\text { length }(\mathrm{m})\end{array}$ \\
\hline 5 April & PISCES IV & 1953 & Cormorant Cove & $47.614^{\circ} \mathrm{N}, 54.065^{\circ} \mathrm{W}^{b}$ & 2.0 & $1100^{c}$ \\
\hline 5 April & SDL-1 & 968 & Cormorant Cove & $47.618^{\circ} \mathrm{N}, 54.062^{\circ} \mathrm{W}^{\mathrm{b}}$ & 2.1 & $1200^{c}$ \\
\hline 21 April & PISCES IV & 1954 & Cormorant Cove & $47.610^{\circ} \mathrm{N}, 54.071^{\circ} \mathrm{W}$ & 5.2 & 2521 \\
\hline 21 April & SDL-1 & 969 & Cormorant Cove & $47.611^{\circ} \mathrm{N}, 54.076^{\circ} \mathrm{W}$ & 5.2 & 3526 \\
\hline 22 April & PISCES IV & 1955 & Cormorant Cove & $47.608^{\circ} \mathrm{N}, 54.072^{\circ} \mathrm{W}$ & 4.7 & 2961 \\
\hline 22 April & SDL-1 & 970 & Cormorant Cove & $47.611^{\circ} \mathrm{N}, 54.073^{\circ} \mathrm{W}$ & 1.7 & 1029 \\
\hline 22 April $^{d}$ & SDL-1 & 971 & Cormorant Cove & $47.608^{\circ} \mathrm{N}, 54.075^{\circ} \mathrm{W}$ & 2.0 & 1374 \\
\hline 23 April & SDL-1 & 972 & Cormorant Cove & $47.620^{\circ} \mathrm{N}, 54.063^{\circ} \mathrm{W}$ & 3.3 & 1880 \\
\hline 24 April & SDL-1 & 973 & Haystack Bank & $47.624^{\circ} \mathrm{N}, 54.013^{\circ} \mathrm{W}$ & 5.3 & 2018 \\
\hline 25 April & SDL-1 & 974 & Haystack Bank & $47.614^{\circ} \mathrm{N}, 54.012^{\circ} \mathrm{W}$ & 0.8 & 634 \\
\hline
\end{tabular}

recorded. All observations were made by personnel who had several years experience identifying various stages of juvenile marine fishes, including Atlantic cod.

The presence of the submersible had no observable effect on the substrate associations and activity patterns of juvenile cod. Individual fish which were 'overtaken' by the submersible did not abruptly change direction or swimming speed from the time of first sighting $(\sim 10 \mathrm{~m}$ in front of the sub) to the time the sub passed over same fish. On several occasions, we stopped the submersible to observe individual fish and detected no changes in their behaviour over 5 or more minutes. During our night dive, we observed one individual age 3 juvenile cod for over $30 \mathrm{~min}$ with the lights on and off, and observed no changes in behaviour. During our survey, a 'bow wave' was created by the submersible (especially at high speed, $\sim 0.5 \mathrm{~m} \mathrm{~s}^{-1}$ ), which extended to as far as $1.5 \mathrm{~m}$ in front. All our observations were made on fish located outside this disturbance.

Observations of substrate, macroalgae cover and bathymetric relief were analysed from the videotape in $1.0 \mathrm{~min}$ increments. Substrate was classified into 6 categories by particle size (diameter): mud/silt $(<0.1 \mathrm{~cm})$; sand/gravel $(0.1$ to $2.0 \mathrm{~cm})$, pebble/cobble $(2.0$ to $25 \mathrm{~cm})$, rock $(25$ to $100 \mathrm{~cm})$, boulder $(>100 \mathrm{~cm})$, and bedrock. Macroalgae (primarily Irish moss and kelp) density was classified into broad categories by percentage of the bottom cover: none $(<1 \%)$ sparse ( 1 to $5 \%$ ), moderate ( 6 to $25 \%$ ), dense $(>25 \%)$. Bathymetric relief was classified as high ( $>10 \%$ slope) or low $(<10 \%$ slope). The proportions of linear distance transected which consisted of these habitat features has been summarized in Table 2. Due to the nature of the terrain, there was no attempt to maintain a constant transect speed. Instead, the habitat features recorded during each $1.0 \mathrm{~min}$ increment were standardized to linear distance transected, during data analysis.
The presence of juvenile and adult cod was recorded as the number observed in each 1.0 min increment; repeat observations on the same individual fish during any given dive were ignored (e.g. an individual which swam out of view and then back in view). Analysis of night observations on the habitat association of juvenile cod was made separately from day observations. We restricted our analysis of the cover use behaviour and substrate association of juvenile cod to those individuals which we could identify to age group on videotape. We identified individuals as 'young' juveniles (Age 1) or 'old' juveniles (Age 2 to 4), on the basis of size and colouration. Young juveniles were approximately 10 to $12 \mathrm{~cm}$ long (total length), were mottled

Table 2. Distance surveyed by submersible which was comprised of specific bottom substrate features, including substrate category (particle size), bathymetric relief, depth strata, and macroalgae, in Placentia Bay, 21-25 April 1995

\begin{tabular}{|lrc|}
\hline Bottom feature & Distance $(\mathrm{m})$ & Percentage \\
\hline Substrate category & & \\
Mud/silt $(<0.1 \mathrm{~cm})$ & 933 & 6 \\
Sand/gravel $(0.1-2.0 \mathrm{~cm})$ & 6297 & 40 \\
Pebble/cobble $(2.0-25 \mathrm{~cm})$ & 3040 & 19 \\
Rock $(25-100 \mathrm{~cm})$ & 1220 & 8 \\
Boulder $(>1 \mathrm{~m})$ & 83 & $<1$ \\
Bedrock & 4242 & 27 \\
Bathymetric relief & & \\
Low $(<10 \%)$ & 11383 & 72 \\
High $(>10 \%)$ & 4480 & 28 \\
Macroalgae $(\%$ bottom cover) & & \\
None/sparse $(<6 \%)$ & 14029 & 88 \\
Moderate/dense $(6-100 \%)$ & 1835 & 12 \\
Depth & & \\
$0-20 \mathrm{~m}$ & 368 & 2 \\
$21-40 \mathrm{~m}$ & 2323 & 15 \\
$41-60 \mathrm{~m}$ & 4101 & 26 \\
$61-80 \mathrm{~m}$ & 4753 & 30 \\
$81-100 \mathrm{~m}$ & 2961 & 19 \\
$>100 \mathrm{~m}$ & 1358 & 9 \\
\hline
\end{tabular}


and generally brown to red in colour. Old juveniles were longer than $15 \mathrm{~cm}$ and were generally more uniform in colour (usually grey or brown), but not mottled. Size was estimated by using common bottom features (e.g. urchins, anemones, occasional bottles and cans) or referencing the background features against parts of the submersible.

The associations of young and old juvenile cod with bottom substrate, depth strata, macroalgae, and bathymetric relief were tested by chi-square analysis of contingency tables. Analysis of cod association by depth and macroalgae were conducted as univariate tests. Such tests suggested the possibility of an interaction between the variables, bathymetric relief and substrate particle size, and cod frequency of occurrence. Therefore, we performed analysis of these associations as chi-square tests of 3-dimensional contingency tables.

We investigated the use of bottom features which could be used as cover from predators by analysing differences in the activity level of young and old juvenile cod, in association with these features. All distance measures for these comparisons were standardized to units of body length (BL) to avoid size related bias. We measured individual swimming speed $\left(B L s^{-1}\right)$ as a representation of activity. With the exception of some old juveniles, preliminary examination of the videotape showed that movements of individuals were generally not directional. Therefore, we considered that the term 'activity' more accurately reflected their behaviour than swimming speed per se. We analyzed the effects of 'distance to cover' and substrate particle size on activity between individuals. These analyses were conducted by examining videotaped records in incre- ments of $0.05 \mathrm{~s}$. We identified 'cover' as the nearest habitat feature (often a rock, boulder, or crevice) to which a particular juvenile fish demonstrated affinity (e.g. moved or oriented toward). If cover could not be identified in this manner, we arbitrarily assigned either the nearest habitat feature greater than $1.0 \mathrm{BL}$ in size or the largest particle within $10 \mathrm{BL}$ of a particular fish (in order of preference) as cover Therefore, our estimates of distance to cover were conservative. Relationships between the distance to cover or size of substrate and mobility were determined by ANOVA (Wilkinson 1988) on log transformed data.

\section{RESULTS}

We made observations on 196 individual juvenile cod ranging in age from 1 to $4 \mathrm{yr}$ old. In addition to juveniles, we observed 3 adult (or maturing) cod, greater than $50 \mathrm{~cm}$ total length (approximately age 6 or older). Young juveniles and old juveniles were found throughout the study area (Fig. 4). Their distribution appeared to be contagious, especially for old juveniles. However, juvenile cod did not at any time demonstrate any activity which could be described as 'schooling'. Most juvenile cod were seen at depths greater than $60 \mathrm{~m}$ (Fig. 5). Older juvenile cod were distributed slightly shallower than younger conspecifics $\left(\chi^{2}=12.73 ; \mathrm{p}=0.005 ; \mathrm{df}=3\right.$; $\mathrm{n}=87$ ).

Approximately $12 \%$ of the area surveyed was covered with moderate to dense macroalgae $(>5 \%$ bottom cover). Juvenile cod were not significantly associated with the presence of macroalgae (Fig. 6). Of juvenile

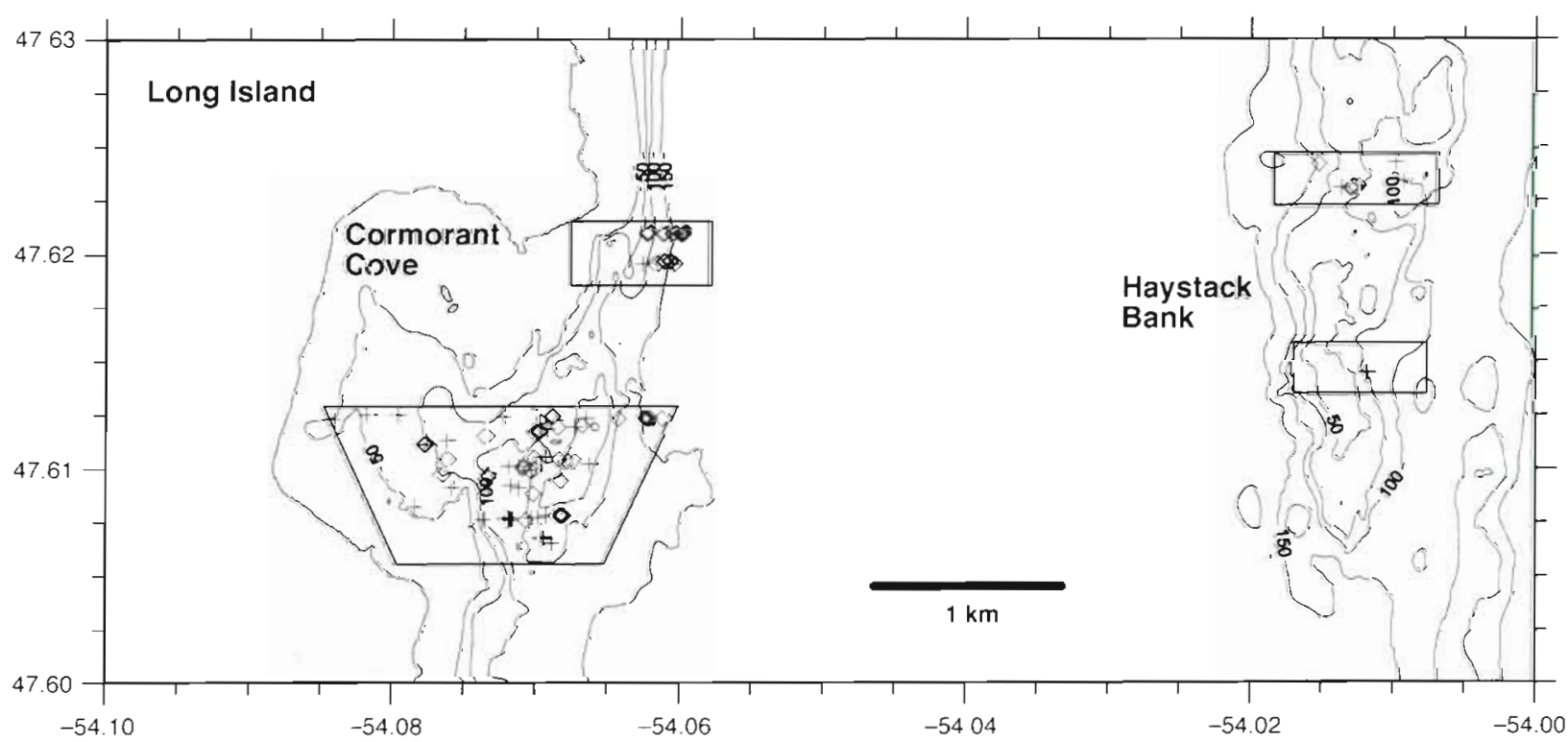

Fig. 4. Gadus morhua. Location of observations of individual young ( + , age 1 ) and old $(\diamond$, age 2 to 4 ) juvenile cod in Cormorant Cove and Haystack Bank, April 1995, as confirmed by videotape analysis 

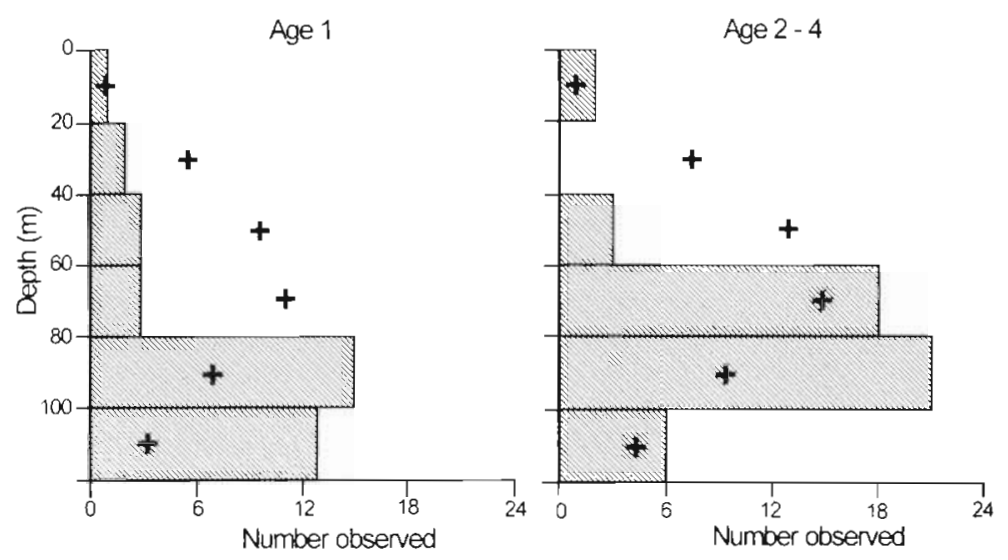

Fig. 5. Gadus morhua. Depth distribution of young (age 1) and old (age 2 to 4) juvenile cod in Cormorant Cove and on Haystack Bank, April 1995 (4, expected number of Juvenile cod if their distribution was proportional to the frequency of occurrence of the depth stratum identified in the submersible

$$
\text { survey) }
$$

cod observed, $11 \%$ of young juveniles and $2 \%$ of old juveniles were present in habitat with moderate to dense macroalgae. Therefore, the data suggested that young juvenile cod neither associated with, nor avoided, macroalgae. Old juveniles were present significantly less frequently in areas with moderate to dense macroalgae than would be expected by chance $\left(\chi^{2}=4.63 ; \mathrm{p}<0.05 ; \mathrm{df}=1 ; \mathrm{n}=50\right)$.

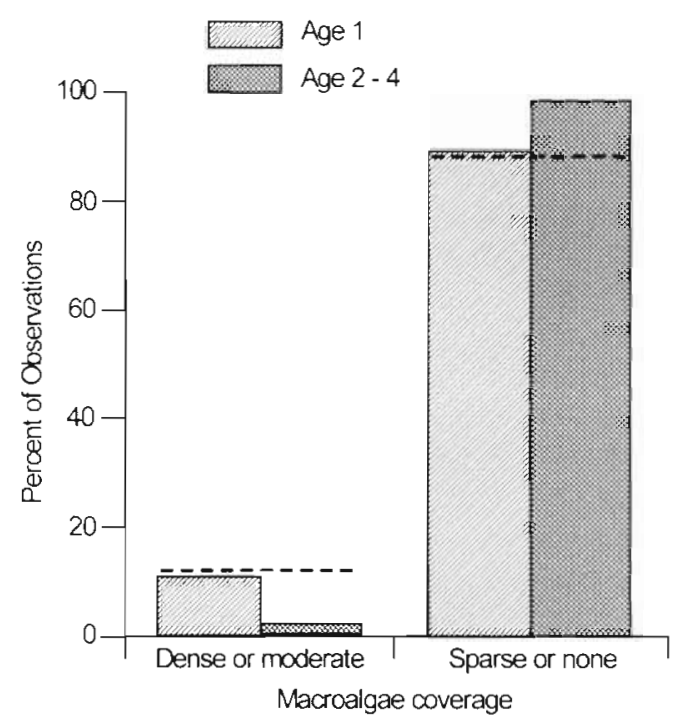

Fig. 6. Gadus morhua. Percent frequency of occurrence of young (age 1) and old (age 2 to 4) juvenile cod in areas of sparse/none and moderate/dense bottom coverage of macroalgae (kelp Laminaria digitata or Agarum cribrosum, and Irish moss Chondrus crispus), Cormorant Cove and Haystack Bank, April 1995 (horizontal dashed lines are the expected number of juvenile cod if their distribution was proportional to the frequency of occurrence of the algae coverage category identified in the submersible survey)
The presence of juvenile cod appeared to be associated with specific combinations of substrate types and bathymetric relief (Fig. 7). These associations also were age specific $\left(\chi^{2}=106.25 ; \mathrm{p}<0.001\right.$; $\mathrm{df}=4 ; \mathrm{n}=83$ ). Old juveniles were more abundant in areas of high bathymetric relief (generally at the base of cliff faces) in coarse substrate, or associated with crevices in bedrock part way up steep inclines and cliffs ( $68 \%$ of observations) despite the fact that such areas represented only $19 \%$ of the distance transected by the submersibles. When present in areas of low bathymetric relief, old juvenile cod were found only over coarse substrates (rock and boulder). The majority of young juveniles were found in areas with gravel substrate ( $59 \%$ of observations) despite the fact that this bottom type represented only $40 \%$ of the survey area (Table 2). However, it did not appear that young juvenile cod avoided any substrate category. The $41 \%$ of young cod that were not associated with gravel substrate appeared to be distributed randomly among the remaining fine and coarse substrate categories $\left(\chi^{2}=0.43 ; \mathrm{p}>0.5 ; \mathrm{df}=1 ; \mathrm{n}=\right.$ $15)$. We did not find any indication that young juveniles avoided areas occupied by older juveniles. In fact, we observed young juveniles in close proximity (within $10 \mathrm{~m}$ ) to older fish in approximately $10 \%$ of cases.

Young juveniles were associated with smaller particle sizes but exhibited higher activity than old juveniles. Young cod exhibited a range of swimming speeds from 0.1 to $6.4 \mathrm{BL} \mathrm{s}^{-1}$ (mean 0.88 $\mathrm{BL} \mathrm{s}^{-1}$; Fig. 8). In contrast, old juveniles were relatively inactive during this study, never exhibiting swimming speeds in excess of $0.9 \mathrm{BL} \mathrm{s}^{-1}$ (mean $0.15 \mathrm{BL} \mathrm{s}^{-1}$; Fig. 8). Both age groups of juvenile were found associated with a wide range of particle sizes, but particle size was not a good predictor of activity for either young or old juveniles (ANOVA, $\mathrm{p}=0.180 ; \mathrm{df}=1,85 ; \mathrm{n}=87$ ). However, activity was positively correlated $\left(r^{2}=0.690\right)$ with distance to cover (Fig. 9) for those old juveniles which did exhibit directional movement (ANOVA, $\mathrm{p}<0.001$; $\mathrm{df}=1,14 ; \mathrm{n}=16$ ). Old juveniles that were not moving (swimming speed $\leq 0.1 \mathrm{BL} \mathrm{s}^{-1}$ ) were generally within $1.5 \mathrm{BL}$ from cover. For old juveniles, cover often consisted of a large particle (e.g. rock, boulder) or a crevice in the bedrock. We had no evidence which supported or refuted a suggestion of territoriality; we observed no agonistic behaviour between nearby individuals. Although higher than that exhibited by older juveniles, the activity of young juvenile cod (Fig. 9) was not correlated with distance from any identifiable cover (ANOVA, $\mathrm{p}=0.610 ; \mathrm{df}=1,35 ; \mathrm{n}=37$ ) 


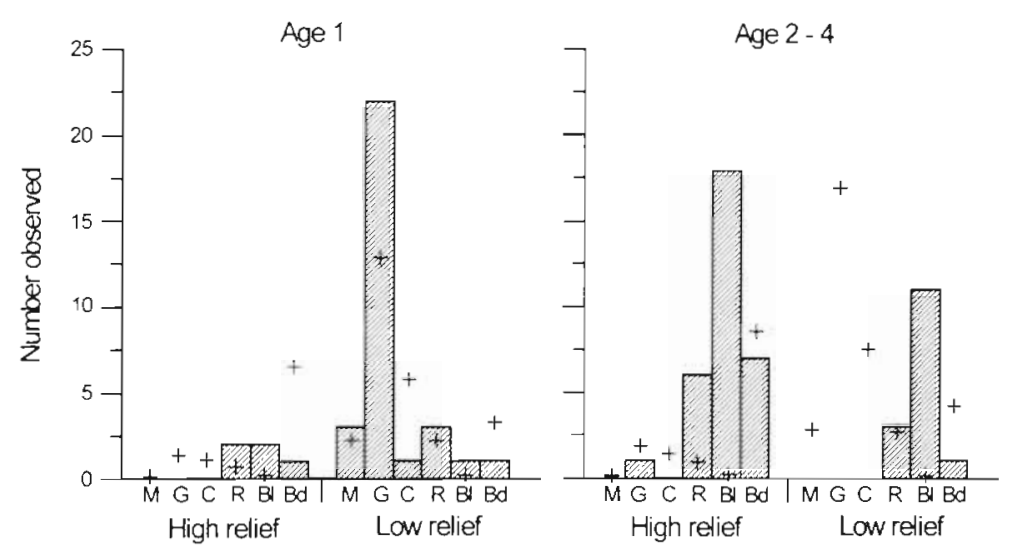

Fig. 7. Gadus morhua. Frequency of observations of young (age 1) and old (age 2 to 4) juvenile cod in areas of bottom habitat in Cormorant Cove and Haystack Bank, April 1995, as defined by bathymetric relief and substrate particle size (substrate categories: $M$, mud/silt; $G$, gravel/sand; $C$, cobble/ pebble; $\mathrm{R}$, rock $\mathrm{B}_{\mathrm{B}} \mathrm{B}$, boulder; $\mathrm{Bd}_{\text {, bedrock }}+$, expected number of juvenile cod if their distribution was proportional to the frequency of occurrence of the substrate and bathymetry conditions identified in the submersible survey)

relief, rocky area. The 1 older juvenile observed at night was associated with a boulder, in an area of high relief. These observations were all similar to those in the day. Activity also did not appear to be different between day and night observations (Fig. 8). There was also little change in the frequency of juvenile cod observations in night versus day relative to the length of the transect (night: $1.6 \operatorname{cod} 100 \mathrm{~m}^{-1}$; day: $1.1 \operatorname{cod} 100 \mathrm{~m}^{-1}$ )

\section{DISCUSSION}

Our study was conducted in April, a time of year associated with low water temperatures in the northwest Atlantic Ocean. The ambient water temperature throughout our study area, at depths of 25 to $75 \mathrm{~m}$, was about $-1.0^{\circ} \mathrm{C}$. Juvenile Atlantic cod are

We observed 3 adult or maturing $\operatorname{cod}(>50 \mathrm{~cm}$ TL) during submersible dives. Upon initial approach, none of these fish appeared to be active. These individuals may have been 'sleeping'. Individuals only moved following several minutes of observation and their swimming speed never exceeded $0.1 \mathrm{BL} \mathrm{s}^{-1}$.

We observed 22 juvenile cod during the night submersible dive. However, due to the low number of individuals for which we have videotape verification of age (8 young and 1 old juvenile), quantification of daynight differences in behaviour and substrate use could not be made with confidence. Qualitatively, however, there were no differences in activity or distribution between day and night suggested by our observations. All young juveniles were observed over gravel substrate, except for 1 individual which was seen in a high

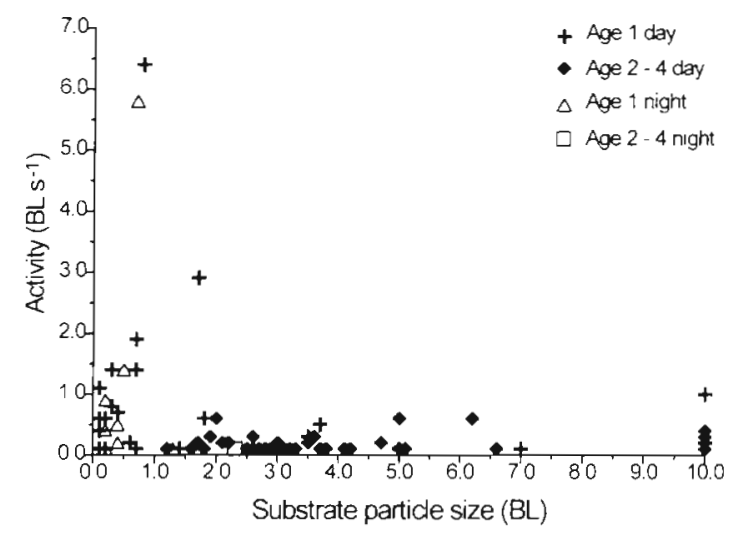

Fig. 8. Gadus morhua. Activity (BL s${ }^{-1} ; \mathrm{BL}=$ body length) of young (age 1) and old (age 2 to 4 ) juvenile cod during day and night observations in Cormorant Cove and Haystack Bank, April 1995, with respect to relative particle size of substrate behaviourally (Brown et al. 1989, Clark \& Green 1991) and physiologically (Goddard et al. 1992) adapted to life in sub-zero water temperatures. Juvenile cod tend to reduce their activity in colder water (Brown et al. 1989). In our study, it appeared that juvenile cod were in a 'winter mode'-moving slowly (and probably infrequently) relative to other times of the year (Gregory \& Anderson unpubl. data). We observed comparatively fewer juvenile cod in warmer shallow waters closer to shore, suggesting that at the time of our observations, these fish preferred lower temperature conditions.

Wigley \& Serchuk (1992) determined that temperature was a contributing factor in explaining the interseasonal spatial and depth distribution of age 1 to $4 \mathrm{cod}$ in the vicinity of the Georges Bank, but it was insufficient to explain observed intraseasonal differences among age classes. Although the winter water temperatures they report $\left(\sim 5^{\circ} \mathrm{C}\right)$ were considerably warmer than those in Placentia Bay, we similarly cannot relate age specific spatial distribution to temperature.

Although not specifically investigated, feeding behaviour by juvenile cod was not observed during the course of this study. There are 2 potential explanations for this: either there is little food available at this time of the year or physiological constraints make the acquisition of this food difficult or energetically unprofitable. We observed capelin Mallotus villosus feeding on an abundance of amphipod and copepod prey at 200 to $250 \mathrm{~m}$ depth. However, we observed no juvenile cod deeper than $130 \mathrm{~m}$. Such invertebrate prey would not have been available to the individual cod observed in our study. Therefore, during the period of study in Placentia Bay, it does not appear that juvenile cod selected habitat for the purposes of feeding. 

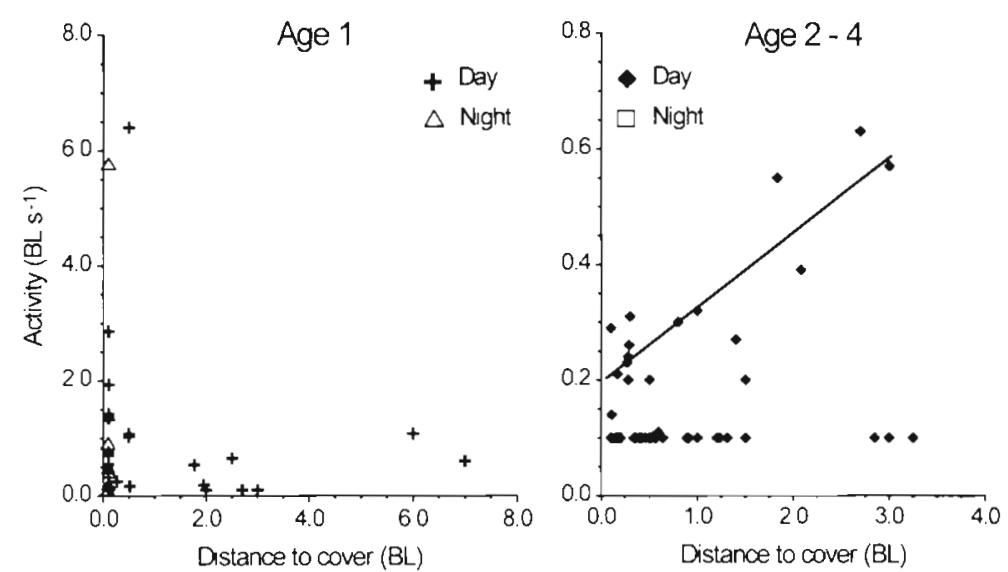

Fig. 9. Gadus morhua. Effect of 'distance to cover' on the day and night activity (BL s${ }^{-1} ; \mathrm{BL}=$ body length) of young (age 1 ) and old (age 2 to 4) juvenile cod, in Cormorant Cove and Haystack Bank, April 1995
We observed juvenile cod throughout most of the range of depths traversed by the submersibles to a depth of $130 \mathrm{~m}$, but they occurred most abundantly at 60 to $120 \mathrm{~m}$. Although the depth distributions of young and old juvenile cod differed statistically, we do not believe these differences were biologically relevant. In Placentia Bay, young and old juvenile cod co-occurred laterally and vertically within our study area. The depth range of juvenile cod distribution was also consistent with previous observations on shallow offshore banks (Lough et al. 1989, Wigley \& Serchuk 1992, Walsh et al. 1995). Observations of the distribution and substrate use of individual juvenile cod have generally been from shallow depths, less than $20 \mathrm{~m}$ (Keats et al. 1987, Keats 1990). However, juvenile cod (age 0 to 2) appear to occur regularly as deep as $100 \mathrm{~m}$ in coastal bays of Newfoundland and offshore onto the shelf (Dalley \& Anderson in press). By tracking acoustically tagged cod inshore, Svendsen (1995) observed that large age 1 juveniles $(21$ to $27 \mathrm{~cm}$ ) inhabit depths inshore ranging from 10 to $30 \mathrm{~m}$. In a tagging experiment, Pihl \& Ulmestrand (1993) found that most age 1 cod were recaptured in less than $10 \mathrm{~m}$ of water, close to shore. Nearshore studies (Methven \& Bajdik 1994, Gotceitas \& Gregory unpubl.) have shown that age $0+$ cod are numerous in depths less than $5 \mathrm{~m}$ nearshore, but that abundance generally decreases from late summer to late fall. Few older individuals were found within $70 \mathrm{~m}$ of shore in either of these studies. These observations suggest that age $0+$ cod move deeper as they grow. Age 1 individuals in spring 1995 would have been age $0+$ individuals the previous fall. Therefore, our observations also support the contention that young cod move into deeper water over time.

Juvenile cod have been shown to exhibit a diel shift in their use of shallow water habitats (Clark \& Green
1990, Keats 1990, Methven \& Bajdik 1994). The abundance of age 1 to $3 \mathrm{cod}$ in shallow waters generally increases at night, and declines during the day as individuals move into deeper water (Clark \& Green 1990, Keats 1990). For example, in a study conducted in coastal Newfoundland in the summer and fall, Clark \& Green (1990) observed that age 3 cod occupied deeper water during the day and shallower water at night. They attributed this diel movement to feeding constraints and physiological demands, although they did not dismiss an antipredator mechanism (e.g. Clark \& Levy 1989). Our night dive observations of juvenile cod use of habitat were not different than those made during the day. Therefore, we suggest that such diel movements do not occur among juvenile cod at spring water temperatures $\left(\sim-1^{\circ} \mathrm{C}\right)$

Laboratory studies have shown that age 0 and 1 juvenile cod exhibit preferences for specific types of substrates based either on particle size or the presence of vegetation (Gotceitas \& Brown 1993, Gotceitas et al. 1995, Fraser et al. 1996). In these studies, it has also been shown that the presence or absence of a predator (an older conspecific) can alter these preferences. Substrate preference is a potent force shaping the distributions (reviewed in Lima \& Dill 1990, Walters \& Juanes 1993) and survival (e.g. Werner et al. 1983, Gotceitas 1990, Gregory \& Levings 1996) of juveniles of many fish species, including cod (Lough et al. 1989, Gotceitas \& Brown 1993, Tupper \& Boutilier 1995b). Gotceitas \& Brown (1993) demonstrated that age 0+ cod can significantly reduce their risk of predation to an older conspecific by selecting coarser substrate (cobble versus sand or gravel). Fraser et al. (1996) showed age $1+$ cod associate with fine substrate (sand) in the absence of a predator, but in the presence of one (an age $3+$ conspecific), young individuals associate with coarser substrate (cobble). Gravel substrate, prominently correlated with our observations of age 1 distribution, was not offered as a choice in their experiments with cod of this age. Recent field studies have also shown that young cod (age $0+$ ) exhibit strong associations with substrate, which gives these fish an advantage both in avoiding detection or capture by predators (Tupper \& Boutilier 1995b) and in growth and survival (Tupper \& Boutilier 1995a, b). In shallow inshore waters ( $<20 \mathrm{~m}$ depth), age 1 to 2 juvenile Atlantic cod are found associated with areas of high wave exposure, rocky substrate and macroalgae during the summer months (Keats et al. 1987). Lough et al. (1989) demonstrated that age 1 cod occupied only a relatively 
small portion of Georges Bank despite the fact that pelagic cod occurred throughout a larger surrounding area. Their data suggested that juvenile cod either were actively selecting the lag-gravel in the smaller, more localized site (in part, to enhance their survival from predators) or were only found in that location due to higher predation mortality in nearby 'unsuitable' habitat. The home ranges of age $3 \mathrm{cod}$ in Conception Bay, Newfoundland, include a large proportion of sandy areas (Clark \& Green 1990). However, in their study of sonically tagged cod, Clark \& Green determined that at night cod rested almost exclusively in rocky areas. Our results corroborated these findings. Older juveniles in our study were rarely present over gravel substrate, but were associated instead with areas of high bathymetric relief and coarser substrates (rock and boulder). In contrast, we observed age 1 cod predominantly over gravel substrates, similar to observations by Lough et al. (1989).

A priori, we had expected to see more juvenile cod in association with macroalgae cover than in its absence. However, our results demonstrated that macroalgae is neither avoided nor preferred by age 1 to 4 juvenile cod. Keats et al. (1987) showed that fleshy macroalgae was a preferred habitat of juvenile cod (age 0 to 2 ) in shallow $(<20 \mathrm{~m}$ ) nearshore areas, during fall. In the laboratory, Gotceitas et al. (1995) showed that the presence of kelp, as well as cobble, increases the survival of age $0+\operatorname{cod}$ in the presence of an actively foraging predator. These authors also demonstrated that macroalgae cover is only preferred in the presence, but not in the absence, of such a predator. It is possible either that there were few predators in the study area or that those present were inactive during our studies. We observed only 3 adult cod during this study. All were inactive when encountered. However, at other times of the year, adult cod are known to be significantly more numerous at our study site (Gregory \& Anderson unpubl.). It is also possible that the physiological or behavioural factors which caused juvenile cod to be found in deeper waters tend to exclude them from areas with large amounts of macroalgae, especially kelp. Such areas occurred mostly in shallower depths $(<40 \mathrm{~m})$ throughout our study site. However, we observed few juvenile cod shallower than $60 \mathrm{~m}$. The lack of a significant correlation between the presence of macroalgae and presence of juvenile cod suggests that juveniles associate with macroalgae only during the summer and fall. It is not clear from published accounts whether juvenile cod use macroalgae primarily for feeding or for predator avoidance. It does appear clear from our results that macroalgae is not used for cover from predators during April, in Placentia Bay.
Our study area was heterogeneous with respect to substrate particle size and bathymetric relief All substrate-relief combinations, with the exception of mud, were within $-200 \mathrm{~m}$ of each other. Therefore, there is little doubt that young and old juvenile cod actively selected the habitat where we observed them. There was no evidence to suggest that young juvenile cod avoided old juveniles or habitat types frequented by them. Young juveniles were observed close (within $10 \mathrm{~m}$ ) to older fish in $10 \%$ of cases. In addition, other than their demonstrated association with low relief gravel areas, young fish showed no significant association with either bathymetric relief or coarse versus fine substrate. This suggests that young juvenile cod did not avoid any particular substrate-relief area, including those occupied by older juveniles.

The activity which young and old juvenile cod exhibited when in association with specific categories of substrate suggested that the 2 age classes were utilizing the substrate differently. Young juveniles were generally more active, but their swimming speed did not appear to be correlated with distance from cover, unlike older juveniles. These trends in activity all suggested a sensitivity to predation threat. Lima \& Dill (1990) have suggested that distance to cover, swimming speed, and escape responses all change in predictable ways in association with an increased threat from a predator. For example, smaller fish will often forage closer to cover in the presence of a predator Fleeing fish will often swim faster toward a refuge when an approaching predator is either swimming more quickly or is larger than predators in previous encounters (Dill 1974). Such antipredator behaviours require that fish (especially those which are small and, presumably, more vulnerable) must be ever vigilant to predatory attack. However, such vigilance has metabolic (Lima \& Dill 1990) and neurological (Dukas \& Clark 1995) costs. Simply stated, it is not always possible to be in a constant state of vigilance. It may be more efficient, and perhaps 'safer' in the long run, to adopt predator averse behaviours which require less vigilance and, therefore, a minimum expenditure of energy. One way fish can achieve this objective is to select appropriate substrate. For cryptic fish (such as age $1+\mathrm{cod}$ ) individuals may select substrate surfaces which match their skin colouration or markings (Donnelly \& Dill 1984). Age O+ juvenile cod (Tupper \& Boutilier 1995b) and age 1+ cod (Lough et al. 1989, this study) generally respond to an approaching object by lying flat against the substrate and remaining motionless, unless approached too closely in which case they burst away at high speed (Gotceitas \& Brown 1993, this study). This behaviour suggests a reliance on crypsis. In our study, the presence of the submersible may have elicited the burst-swim response. For non-cryptically 
coloured animals (such as age 2 to 4 cod) appropriate habitat may include substrate which contains available hiding places, such as rocks, boulders, crevices, and vegetation, which are also close to available food supplies (Walters \& Juanes 1993). Since cod feed little-if at all-in winter (Brown et al. 1989), the substrate choice which would promote maximum survival would simply be that which offered the greatest protection from predators.

In this study, we demonstrated that age 1 to 4 juvenile cod exhibit age-specific associations with substrate. From their patterns of activity in relation to cover, these fish appeared likely to be using specific substrate characteristics for protection from predators. These activity patterns also appeared to change with age, suggesting that the behavioural mechanisms of predator avoidance for cod are also age-specific. Our observations were consistent with those of other researchers working on young Atlantic cod in nearshore and offshore waters as well as the laboratory, but represent the first account of age-related changes in substrate selection and use of available cover by juvenile cod. Our results suggest that substrate which is ideal for one age group of cod may be completely inappropriate for another

Juvenile cod mortality is density-dependent (Myers \& Cadigan 1993), which suggests that demersal habitat may be limiting in some cases. Our results suggest that density-dependent factors could also be important well into the demersal juvenile stage for cod in instances where the availability of heterogeneous bottom habitat is low. During the time of our study, Atlantic cod stocks were at their lowest recorded levels. It is therefore unlikely that habitat for juvenile cod will be limiting for many years to come, in all but the most localized situations. However, it is important that we recognize the importance of specific types of habitat as the process of rebuilding stocks of this commercial fish species continues. In consideration of this end, conservation initiatives directed at the preservation of cod nursery habitat will be more likely to succeed if habitat complexity is considered.

Acknowledgements. This study was financially supported by an award from the Environmental Innovations Program of Environment Canada, the Interim Funding Research Program, and the Department of Fisheries and Oceans (DFO). Arnold Murphy, Edgar Dalley, Eugene MacDonald, Gerard Conan, Dan Porter of DFO contributed invaluable scientific observations, enthusiasm, and technical support. We are especially indebted to the Canadian Navy, specifically LCDR John Creber, LCDR Robert ' $G W$ ' Gwalshmai, the crew of HMCS 'Cormorant' and pilots of PISCES IV and SDL-1 submersibles, without whose help this study could not have been conducted. This paper benefited from the comments of $\mathrm{E}$ Dalley, S. Fraser, V Gotceitas, and 2 anonymous referees This is Ocean Sciences Centre contribution no. 274

\section{LITERATURE CITED}

Able KW, Grimes CB, Cooper RA, Uzmann JR (1982) Burrow construction and behavior of tilefish, Lopholatilus chamaeleonticeps, in Hudson Submarine Canyon. Environ Biol Fish 7:199-205

Anderson JT, Dalley EL, Carscadden JE (1995) Abundance and distribution of pelagic 0-group cod (Gadus morhua) in Newfoundland waters: inshore versus offshore. Can J Fish Aquat Sci 52:115-125

Brown JA, Pepin P, Methven DA, Somerton DC (1989) The feeding, growth and behavour of juvenile cod, Gadus morhua L., in cold environments. J Fish Biol 35:373-380

Clark CW, Levy DA (1989) Diel vertical migrations by pelagic planktivorous fishes and the antipredator window. Am Nat 131:271-290

Clark DS, Green JM (1990) Activity and movement patterns of juvenile Atlantic cod. Gadus morhua, in Conception Bay, Newfoundland, as determined by sonic telemetry. Can J Zool 68:1434-1442

Clark DS, Green JM (1991) Seasonal variation in temperature preference of juvenile Atlantic cod (Gadus morhua), with evidence supporting an energetic basis for their diel vertical migration. Can J Zool 69:1302-1307

Dalley EL, Anderson JT (in press) Age dependent distribution of demersal juvenile cod (Gadus morhua) in inshore/offshore northeast Newfoundland. Can J Fish Aquat Sci 54 (Suppl 1)

Dill LM (1974) The escape response of the zebra danio (Brachydanio rerio). II. The effect of experience. Anim Behav 22:723-730

Donnelly WA, Dill LM (1984) Evidence for crypsis in coho salmon, Oncorhynchus kisutch (Walbaum) parr: substrate colour preference and achromatic reflectance. J Fish Biol 25:183-195

Dukas R, Clark CW (1995) Sustained vigilance and animal performance. Anim Behav 49:1259-1267

Edsall TA, Kennedy GW, Horns WH. (1993) Distribution, abundance, and resting microhabitat of burbot on Julian's Reef, southwestern Lake Michigan. Trans Am Fish Soc 122:560-574

Fraser S, Gotceitas V, Brown JA (1996) Interactions between age-classes of Atlantic cod and their distribution among bottom substrates. Can J Fish Aquat Sci 53:305-314

Goddard SV, Kao MH, Fletcher GL (1992) Antifreeze production, freeze resistance, and overwintering of juvenile northern Atlantic cod (Gadus morhua). Can J Fish Aquat Sci 49:516-522

Gotceitas V (1990) Foraging and predator avoidance: a test of a patch choice model with juvenile bluegill sunfish Oecologia 83:346-351

Gotceltas V. Brown JA (1993) Substrate selection by juvenile Atlantic cod (Gadus morhua): effects of predation risk. Oecologia 93:346-351

Gotceitas V, Fraser S, Brown JA. (1995) Habitat use by juvemle Atlantic cod (Gadus morhua) in the presence of an actively foraging and non-foraging predator. Mar Biol 123 $421-430$

Gregory RS, Anderson JT, Dalley EL (1996) Use of habitat information in conducting assessments of juvenile cod abundance. NAFO (Northwest Atl Fish Organ) SCR Doc $96 / 23$

Gregory RS, Levings CD (1996) The effects of turbidity and vegetation on the risk of juvenile salmonids, Oncorhynchus spp., to predation by adult cutthroat trout, $O$. clarkii Environ Biol Fish 47:279-288

Grimes CB, Able KW, Jones RS (1986) Tilefish, Lopholatilus 
chamaeleonticeps, habitat, behavior and community structure in mid-Atlantic and southern New England waters. Environ Biol Fish 15:273-292

Ings DW, Schneider DC, Methven DA (in press) Detection of a recruitment signal in juvenile Atlantic cod Gadus morhua L.) in coastal nursery areas. Can J Fish Aquat Sci 54 (Suppl 1)

Keats DW (1990) A nocturnal inshore movement of juvenile cod Gadus morhua L. in eastern Newfoundland. J Exp Mar Biol Ecol 139:167-173

Keats DW, Steele DH, South GR (1987) The role of fleshy macroalgae in the ecology of juvenile cod (Gadus morhua L.) in inshore waters off eastern Newfoundland. Can $\mathrm{J}$ Zool 65:49-53

Krieger KJ (1993) Distribution and abundance of rockfish determined from a submersible and by bottom trawling. Fish Bull US 91:87-96

Lear HW, Fleming AM, Wells R (1980) Results of small cod surveys in eastern Newfoundland during 1959-1964. NAFO (Northwest Atl Fish Organ) SCR Doc 80/IX/144 No. N2.18

Lima SL, Dill LM (1990) Behavioral decisions made under the risk of predation: a review and prospectus. Can J Zool 68:619-640

Lough RG, Valentine PC, Potter DC, Auditore PJ, Bolz GR, Neilson JD. Perry RI (1989) Ecology and distribution of juvenile cod and haddock in relation to sediment type and bottom currents on eastern Georges Bank. Mar Ecol Prog Ser 56:1-12

Methven DA, Bajdik C (1994) Temporal variation in size and abundance of juvenile Atlantic cod (Gadus morhua) at an inshore site off eastern Newfoundland. Can J Fish Aquat Sci 51:78-90

Myers RA, Cadigan NG (1993) Is juvenile natural mortality in marine demersal fish variable? Can J Fish Aquat Sci 50: $1591-1598$

O'Connell VM, Carlile DW (1994) Comparison of a remotely operated vehicle and a submersible for estimating abundance of demersal shelf rockfishes in the eastern Gulf of Alaska. N Am J Fish Manage 14:196-201

Pihl L, Ulmestrand M (1993) Migration pattern of juvenile cad

This article was presented by C. H. Peterson (Senior Editorial Advisor), Morehead City, North Carolina, USA
(Gadus morhua) on the Swedish west coast. ICES J Mar Sci 50:63-70

Riley JD, Parnell WG (1984) The distribution of young cod. In: Dahl E, Danielssen DS, Moksness E, Solemdal P (eds) The propagation of cod Gadus morhua L. Oluf Rasmussen As, Skien, p 563-580

Starr RM, Fox DS, Hixon MA, Tissot BN, Johnson GE, Barss WH (1996) Comparison of submersible-survey and hydroacoustic-survey estimates of fish density on a rocky bank. Fish Bull US 94:113-123

Svendsen YS (1995) Tracking juvenile cod (Gadus morhua L.) in northern Norway using acoustic tags. Fish Res 23:311-318

Templeman W (1979) Migration and intermingling of stocks of Atlantic cod, Gadus morhua, of Newfoundland and adjacent areas from tagging in 1962-1966. ICNAF (Int Comm Northwest Atl Fish) Res Bull 4:5-50

Tupper M, Boutilier RG (1995a) Size and priority at settlement determine growth and competitive success of juvenile Atlantic cod. Mar Ecol Prog Ser 118:295-300

Tupper M, Boutilier RG (1995b) Effects of habitat on settlement, growth, and postsettlement survival of Atlantic cod (Gadus morhua). Can J Fish Aquat Sci 52:1834-1841

Walsh SJ, Brodie WB, Bishop CA, Murphy EF (1995) Fishing on juvenile groundfish nurseries on the Grand Bank: a discussion of technical measures of conservation. In: Shackell NL, Willison JHM (eds) Marine protected areas and sustainable fisheries. Sci Manag Protected Areas Assoc, Wolfville, p $54-73$

Walters CL, Juanes F (1993) Recruitment limitation as a consequence of natural selection for use of restricted feeding habitats and predation risk taking by juvenile fishes. Can J Fish Aquat Sci 50:2058-2070

Werner EE, Gilliam JF, Hall DJ, Mittelbach GG (1983) Experimental tests of optimal habitat use in fish: the role of relative habitat profitability. Ecology 64:1525-1539

Wigley SE, Serchuk FM (1992) Spatial and temporal distribution of juvenile Atlantic cod Gadus morhua in the Georges Bank-southern New England region. Fish Bull US 90: 599-606

Wilkinson L (1988) SYSTAT: the system for statistics. Evanston, IL

Manuscript first received: April 21, 1996

Revised version accepted: November 14, 1996 